\title{
Extending Combination Therapy with Peginterferon plus Ribavirin for Genotype 2 Chronic Hepatitis C Virological Responders: A Pilot Study of 7 Cases
}

\author{
Norio Akuta ${ }^{a}$ Fumitaka Suzuki ${ }^{a}$ Yasuji Arase $^{a}$ Miharu Hirakawa ${ }^{a}$ \\ Yusuke Kawamura $^{a}$ Hiromi Yatsuji ${ }^{a}$ Hitomi Sezaki ${ }^{a}$ Yoshiyuki Suzukia \\ Tetsuya Hosaka ${ }^{a}$ Masahiro Kobayashi ${ }^{a}$ Mariko Kobayashi ${ }^{b}$ Satoshi Saitoh ${ }^{a}$ \\ Kenji Ikeda ${ }^{a}$ Hiromitsu Kumada ${ }^{a}$ \\ a Department of Hepatology and ${ }^{b}$ Liver Research Laboratory, Toranomon Hospital, Tokyo, Japan
}

\section{Key Words}

Hepatitis $C$ virus - Genotype $2 \cdot$ Interferon - Ribavirin .

Combination therapy, extended $\cdot$ Early virological response

\begin{abstract}
Objective: In treatment-resistant patients with genotype 2 chronic hepatitis $C$ the suitable treatment duration is still unclear. The aims were to investigate extending combination therapy with peginterferon plus ribavirin for genotype 2 . Methods: 7 patients infected with genotype 2 at a high viral load and who did not achieve a sustained virological response (SVR) with the first course of 24-week IFN plus ribavirin were recruited into the study protocol with a total of 48 weeks of peginterferon plus ribavirin therapy. Results: SVR was achieved in 5 of 7 patients (71\%). All 4 patients (100\%) who were in relapse with the first course achieved SVR. Only 1 of 3 patients (33\%) who had a non-virological response (NVR) with the first course achieved SVR. All 4 patients who had an early virological response (EVR) with the first course achieved EVR and SVR. Two of 3 patients who had no EVR with the first course also did not achieve EVR and SVR. One
\end{abstract}

patient who had no EVR or a NVR during the first course achieved EVR and SVR with the second course. Conclusions: Our results suggest that extending combination therapy for genotype 2 chronic hepatitis $C$ might be useful for patients who relapse following 24-week combination therapy.

Copyright $\odot 2010$ S. Karger AG, Basel

\section{Introduction}

The response to interferon (IFN)-related therapy varies according to hepatitis $\mathrm{C}$ virus (HCV) genotype $[1,2]$. In Japan, about $70 \%$ of patients with chronic hepatitis $\mathrm{C}$ are infected with $\mathrm{HCV}$ genotype $1 \mathrm{~b}$, and about $25 \%$ are genotype 2a [3]. The sustained virological response (SVR) to 48 -week IFN plus ribavirin combination therapy is about $50 \%$ in genotype 1 b infection, and the SVR to 24 week combination therapy is more than $80 \%$ in genotype 2 infection [4-9].

IFN plus ribavirin combination therapy carries potential serious side effects and is costly especially when used long enough to achieve a high SVR. For these reasons,

\section{KARGER}

Fax +41 613061234 E-Mail karger@karger.ch www.karger.com
(C) 2010 S. Karger AG, Basel

0300-5526/10/0533-0188\$26.00/0

Accessible online at:

www.karger.com/int
Norio Akuta, MD

Department of Hepatology

Toranomon Hospital

2-2-2 Toranomon, Minato-ku, Tokyo 105-0001 (Japan)

Tel. +81 44877 5111, Fax +81 44860 1623, E-Mail akuta-gi@umin.ac.jp 
especially in genotype 2 infection, it is necessary to identify those patients who could achieve SVR with a shorter treatment course (16 weeks or less) to free them of unnecessary side effects and reduce costs, preferably as early as possible [6-8]. However, we also sometimes encounter treatment-resistant patients infected with genotype $2[3$, $10,11]$. Our recent report based on 24 -week combination therapy showed that $17.5 \%$ of patients infected with genotype 2a were not able to achieve SVR, and especially that 81.5 and $18.5 \%$ of the non-SVR patients were in relapse or had a non-viral response (NVR), respectively [11]. Thus, the suitable treatment duration, based on the consideration of risk/benefit and cost/benefit, is still unclear in patients infected with genotype 2 .

The present study included 7 Japanese adults with genotype 2 and a high viral load, who received a second course of combination therapy. The aims of the study were to investigate extending combination therapy with peginterferon (PEG)- $\alpha-2 b$ plus ribavirin for genotype 2 chronic hepatitis $\mathrm{C}$.

\section{Materials and Methods}

\section{Study Population}

A total of $292 \mathrm{HCV}$ genotype 2-infected Japanese adult patients were consecutively recruited into the study protocol of the combination therapy with IFN (PEG-IFN $\alpha-2 b$ or IFN $\alpha-2 b)$ plus ribavirin for 24 weeks between March 2002 and September 2008 at Toranomon Hospital, Tokyo, Japan. Among these, 7 of 52 patients who were not able to achieve a sustained virological response were recruited into the study protocol of 48 -week combination therapy with PEG-IFN $\alpha-2 b$ plus ribavirin. They fulfilled the following inclusion criteria: (1) no SVR with the first course of combination therapy regardless of completing the 24-week therapy; (2) combination therapy was stopped before completing the 24-week therapy due to a decrease in HCV RNA of $<2.0$ log at 12 weeks after starting treatment based on qualitative PCR analysis $[12,13]$; (3) negative for hepatitis B surface antigen (radioimmunoassay, Dainabot, Tokyo, Japan), positive for anti-HCV (third-generation enzyme immunoassay, Chiron Corp, Emerville, Calif., USA), and positive for HCV RNA qualitative analysis with PCR (Amplicor, Roche Diagnostic Systems, Pleasanton, Calif., USA); (4) infected with HCV genotype $2 \mathrm{a}$ or $2 \mathrm{~b}$ alone; (5) high viral load $(\geq 100 \mathrm{KIU} / \mathrm{ml})$ by quantitative analysis of $\mathrm{HCV}$ RNA with PCR (Amplicor GT HCV Monitor v2.0 using the 10fold dilution method, Roche Molecular Systems Inc.) within the 2 months preceding enrolment; (6) no hepatocellular carcinoma; (7) body weight $>40 \mathrm{~kg}$; (8) no co-infection with human immunodeficiency virus; (9) no treatment with antiviral or immunosuppressive agents within the 3 months preceding enrolment; (10) no alcoholics, lifetime cumulative alcohol intake $<500 \mathrm{~kg}$ (mild to moderate alcohol intake); (11) no other form of hepatitis, such as hemochromatosis, Wilson disease, primary biliary cirrhosis, alcoholic liver disease, and autoimmune liver disease; (12) no pregnant or lactating females; (13) all patients completed a 24week follow-up program after cessation of treatment and SVR could be evaluated, and (14) each signed a form consenting to the study protocol that had been approved by the human ethics review committee.

Treatment efficacy was defined as: SVR $=$ HCV-RNA-negative based on qualitative PCR analysis 24 weeks after the completion of treatment; relapse $=\mathrm{HCV}$-RNA-negative at completion of treatment but HCV-RNA-positive 24 weeks after the completion, and NVR = HCV-RNA-positive at completion of treatment. Furthermore, an early virological response (EVR) was defined as patients who achieved a decrease in HCV-RNA of $>2.0 \log$ within 12 weeks after starting treatment, based on quantitative PCR analysis.

\section{Laboratory Tests}

Blood samples were obtained at least once every month before, during, and after treatment, and were analyzed for alanine aminotransferase and HCV-RNA levels. The serum samples were frozen at $-80^{\circ}$ within $4 \mathrm{~h}$ of collection and thawed at the time of measurement. HCV genotype was determined by PCR using a mixed primer set derived from the nucleotide sequences of NS5 region [14]. HCV-RNA levels were measured by quantitative PCR (Amplicor GT HCV Monitor v2.0 using the 10-fold dilution method, Roche Molecular Systems Inc.) at least once every month before, during, and after therapy. The dynamic range of the assay was $5-5,000 \mathrm{KIU} / \mathrm{ml}$. Samples collected during and after therapy that showed undetectable levels of HCV-RNA $(<5 \mathrm{KIU} / \mathrm{ml})$ were also checked by qualitative PCR (Amplicor HCV v2.0, Roche Molecular Systems Inc.), which has a higher sensitivity than quantitative analysis, and the results are expressed as positive or negative. The lower limit of the assay was $50 \mathrm{IU} / \mathrm{ml}$.

\section{Histopathological Examination of Liver Biopsies}

Liver biopsy specimens were obtained percutaneously or at peritoneoscopy using a modified Vim Silverman needle with an internal diameter of $2 \mathrm{~mm}$ (Tohoku University style, Kakinuma Factory, Tokyo, Japan), fixed in 10\% formalin, and stained with hematoxylin and eosin, Masson's trichrome, silver impregnation, and periodic acid-Schiff after diastase digestion. All specimens for examinations contained 6 or more portal areas. Histopathological diagnosis was confirmed by an experienced liver pathologist (H.K.) who was blinded to the clinical data. Chronic hepatitis was diagnosed based on histological assessment according to the scoring system of Desmet et al. [15].

\section{Results}

Table 1 summarizes the characteristics of the 7 patients at commencement of the second-course combination therapy with PEG-IFN plus ribavirin. There were 5 men and 2 women, aged 40-65 (median 55) years. Two cases were genotype $2 \mathrm{a}$, and the other 5 cases were genotype $2 \mathrm{~b}$. They received PEG-IFN $\alpha-2 \mathrm{~b}$ at a median dose of 1.4 (range 1.1-1.7) $\mu \mathrm{g} / \mathrm{kg}$ subcutaneously each week. They also received oral ribavirin at a median dose of 10.6 
Table 1. Baseline characteristics of patients infected with HCV genotype 2 at the commencement of the second-course combination therapy with peginterferon plus ribavirin, and treatment efficacy of the first and second course of combination therapy

\begin{tabular}{|c|c|c|c|c|c|c|c|c|c|c|}
\hline $\begin{array}{l}\text { Case } \\
\text { No. }\end{array}$ & Genotype & Sex & $\begin{array}{l}\text { Age } \\
\text { years }\end{array}$ & Fibrosis & $\begin{array}{l}\text { ALT } \\
\text { IU/l }\end{array}$ & $\begin{array}{l}\text { HCV RNA } \\
\mathrm{KIU} / \mathrm{ml}\end{array}$ & $\begin{array}{l}1 \text { st } \\
\text { EVR }\end{array}$ & $\begin{array}{l}1 \mathrm{st} \\
\mathrm{Tx}\end{array}$ & $\begin{array}{l}\text { 2nd } \\
\text { EVR }\end{array}$ & $\begin{array}{l}\text { 2nd } \\
\text { Tx }\end{array}$ \\
\hline 1 & $2 b$ & M & 48 & $\mathrm{~F} 1$ & 41 & 5,000 & + & relapse & + & SVR \\
\hline 2 & $2 b$ & $\mathrm{~F}$ & 65 & $\mathrm{~F} 1$ & 35 & 1,200 & + & relapse & + & SVR \\
\hline 3 & $2 b$ & M & 51 & F3 & 71 & 310 & + & relapse & + & SVR \\
\hline 4 & $2 b$ & M & 56 & $\mathrm{~F} 1$ & 78 & 720 & + & relapse & + & SVR \\
\hline 5 & $2 \mathrm{a}$ & M & 57 & $\mathrm{~F} 1$ & 240 & 1,500 & - & NVR & + & SVR \\
\hline 6 & $2 a$ & M & 40 & $\mathrm{~F} 2$ & 434 & 650 & - & NVR & - & NVR \\
\hline 7 & $2 b$ & $\mathrm{~F}$ & 55 & F3 & 132 & 1,300 & - & NVR & - & NVR \\
\hline
\end{tabular}

EVR = Early virological response; NVR = non-virological response; SVR = sustained virological response; 1 st EVR = EVR with the first course of combination therapy; $2 \mathrm{nd} \mathrm{EVR}=\mathrm{EVR}$ with the second course of combination therapy; $\mathrm{Tx}=$ treatment.

(range 7.0-12.6) $\mathrm{mg} / \mathrm{kg}$ daily. In 3 patients (cases 1, 3, 7), the dose of ribavirin was reduced during treatment due to a fall in $\mathrm{Hb}$ concentration. Five patients (cases 1-5) achieved EVR and completed a total of 48 weeks. The other 2 patients did not achieve EVR, so they stopped combination therapy before completing the 48-week therapy (12 weeks for case 6, and 22 weeks for case 7).

\section{Virological Response Rates with the Second Course of} Combination Therapy

SVR was achieved by 5 of 7 patients (71.4\%). All 4 patients (100\%) who were in relapse with the first course of combination treatment achieved SVR with the second course. However, only 1 of 3 patients (33.3\%) who had a NVR with the first course achieved SVR. All 4 patients (100\%) who had an EVR with the first course achieved EVR and SVR with the second course. However, 2 of 3 patients (cases 6,7) who had no EVR with the first course also did not have EVR and SVR with the second course. Thus, 2 patients (cases 6, 7) had no EVR and NVR with both the first and second courses, and could not achieve SVR. Interestingly, 1 patient (case 5) who had no EVR or NVR with the first course achieved EVR and SVR with the second course.

\section{Discussion}

In patients infected with genotype 1, previous studies have demonstrated that SVR rates of late virological responders (HCV-RNA-positive at 12 weeks and negative 24 weeks after the start of treatment) could be improved when treatment was extended to 72 weeks, compared with a standard treatment duration of 48 weeks, largely as a result of reducing post-treatment relapse rates [1620]. Thus, prolongation of therapy in genotype 1 may improve the virological response rate. However, it is not clear at present whether prolongation of treatment improves the SVR rate of treatment-resistant Japanese patients infected with genotype 2 . This study of patients infected with genotype 2 showed that SVR rates of patients who were EVR and relapsed following the first course with a standard treatment duration of 24 weeks could be improved when treatment was extended to 48 weeks. Interestingly, 1 patient (case 5) who did not have EVR or NVR with the first course achieved EVR and SVR with the second course. This indicates that the SVR rates of patients who had an EVR with the second course might improve further by extending combination therapy regardless of NVR with the first course. To our knowledge, this is the first report to indicate that extending combination therapy to 48 weeks for genotype 2 might be useful.

In this study, 2 patients did not have an EVR or an NVR with both the first and second course and could not achieve SVR. The underlying mechanism(s) of the different virological responses to treatment in patients infected with genotype 2 is still unclear. Previous reports indicated that viral factors (e.g. viral load, aa substitutions in the NS5A region and core region, early viral kinetics, and periods from the start of treatment to initial point of undetectable HCV-RNA) and host factors (e.g. body mass index, fibrosis stage, and hepatocyte steatosis) might be important predictors of treatment response to IFN-related therapy in patients infected with HCV genotype $2 a$, in addition to treatment-related factors (e.g. treatment duration, and ribavirin dose) [6-11, 21-27]. One of the lim- 
itations to this study is that due to the small number of patients we were not able to investigate treatment-resistant factors. Further studies should be performed to identify these viral and host factors before the start of combination therapy. Furthermore, more effective therapeutic regimens, including triple therapy with PEG-IFN plus ribavirin and telaprevir, should be developed for these patients who could not achieve SVR by extending dual therapy of PEG-IFN plus ribavirin.

In conclusion, our results suggest that extending combination therapy to 48 weeks for genotype 2 chronic hep- atitis $\mathrm{C}$ might be useful for patients who had a relapse following the first course of 24-week combination therapy. In the future a large-scale prospective study based on intention-to-treat analysis should be conducted to confirm the above findings.

\section{Acknowledgement}

This study was supported in part by a Grant-in-Aid from the Ministry of Health, Labor and Welfare, Japan.

\section{References}

1 Simmonds P: Clinical relevance of hepatitis C virus genotypes. Gut 1997;40:291-293.

-2 Haydon GH, Jarvis LM, Blair CS, Simmonds P, Harrison DJ, Simpson KJ, Hayes PC: Clinical significance of intrahepatic hepatitis $\mathrm{C}$ virus levels in patients with chronic HCV infection. Gut 1998;42:570-575.

3 Akuta N, Suzuki F, Tsubota A, Suzuki Y, Someya T, Kobayashi M, Saitoh S, Arase Y, Ikeda K, Kumada H: Efficacy of interferon monotherapy to 394 consecutive naive cases infected with hepatitis $C$ virus genotype $2 \mathrm{a}$ in Japan: therapy efficacy as consequence of tripartite interaction of viral, host and interferon treatment-related factors. J Hepatol 2002;37:831-836.

-4 Manns MP, McHutchison JG, Gordon SC, Rustgi VK, Shiffman M, Reindollar R, Goodman ZD, Koury K, Ling MH, Albrecht JK: Peginterferon alfa-2b plus ribavirin compared with interferon alfa-2b plus ribavirin for initial treatment of chronic hepatitis $\mathrm{C}$ : a randomized trial. Lancet 2001;358:958-965.

5 Fried MW, Shiffman ML, Reddy R, Smith C, Marinos G, Gonçales FL, Häussinger D, Diago M, Carosi G, Dhumeaux D, Craxi A, Lin A, Hoffman J, Yu J: Peginterferon alfa-2a plus ribavirin for chronic hepatitis $\mathrm{C}$ virus infection. N Engl J Med 2002;347:975-982.

-6 Mangia A, Santoro R, Minerva N, Ricci GL, Carretta V, Persico M, Vinelli F, Scotto G, Bacca D, Annese M, Romano M, Zechini F, Sogari F, Spirito F, Andriulli A: Peginterferon alfa-2b and ribavirin for 12 versus 24 weeks in HCV genotype 2 or 3. N Engl J Med 2005;352:2609-2617.

7 Mangia A, Minerva N, Bacca D, Cozzolongo R, Agostinacchio E, Sogari F, Scotto G, Vinelli F, Ricci GL, Romano M, Carretta V, Petruzzellis D, Andriulli A: Determinants of relapse after a short (12 weeks) course of antiviral therapy and re-treatment efficacy of a prolonged course in patients with chronic hepatitis $C$ virus genotype 2 or 3 infection. Hepatology 2009;49:358-363.
8 von Wagner M, Huber M, Berg T, Hinrichsen $\mathrm{H}$, Rasenack J, Heintges T, Bergk A, Bernsmeier C, Häussinger D, Herrmann E, Zeuzem S: Peginterferon-alpha-2a (40KD) and ribavirin for 16 or 24 weeks in patients with genotype 2 or 3 chronic hepatitis C. Gastroenterology 2005;129:522-527.

\9 Fujiwara K, Yokosuka O, Komine F, Moriyama M, Kato N, Yoshida H, Tanaka N, Imazeki F, Shiratori Y, Arakawa Y, Omata M; Tokyo Hepatitis Network: Twenty-four weeks of interferon alpha-2b in combination with ribavirin for Japanese hepatitis C patients: sufficient treatment period for patients with genotype 2 but not for patients with genotype 1. Liver Int 2006;26:520-528.

10 Akuta N, Suzuki F, Tsubota A, Suzuki Y, Ho saka T, Someya T, Kobayashi M, Saitoh S, Arase Y, Ikeda K, Kumada H: Association of amino acid substitution pattern in nonstructural protein $5 \mathrm{~A}$ of hepatitis $\mathrm{C}$ virus genotype 2 a low viral load and response to interferon monotherapy. J Med Virol 2003;69: 376-383.

11 Akuta N, Suzuki F, Hirakawa M, Kawamura Y, Yatsuji H, Sezaki H, Suzuki Y, Hosaka T, Kobayashi M, Kobayashi M, Saitoh S, Arase Y, Ikeda K, Kumada H: Association of amino acid substitution pattern in core protein of hepatitis $C$ virus genotype 2 a high viral load and virological response to interferon-ribavirin combination therapy. Intervirology 2009;52:301-309.

$\checkmark 12$ Fried MW, Shiffman ML, Reddy KR, Smith C, Marinos G, Gonçales FL Jr, Häussinger D, Diago M, Carosi G, Dhumeaux D, Craxi A, Lin A, Hoffman J, Yu J: Peginterferon alfa-2a plus ribavirin for chronic hepatitis $\mathrm{C}$ virus infection. N Engl J Med 2002;347:975-982.

13 Davis GL, Wong JB, McHutchison JG, Manns MP, Harvey J, Albrecht J: Early virologic response to treatment with peginterferon alfa-2b plus ribavirin in patients with chronic hepatitis C. Hepatology 2003;38: 645-652.
14 Chayama K, Tsubota A, Arase Y, Saitoh S, Koida I, Ikeda K, Matsumoto T, Kobayashi M, Iwasaki S, Koyama S, Morinaga T, Kumada $\mathrm{H}$ : Genotypic subtyping of hepatitis $\mathrm{C}$ virus. J Gastroenterol Hepatol 1993;8:150156.

$\checkmark 15$ Desmet VJ, Gerber M, Hoofnagle JH, Manna M, Scheuer PJ: Classification of chronic hepatitis: diagnosis, grading and staging. Hepatology 1994;19:1513-1520.

$\checkmark 16$ Buti M, Valdés A, Sánchez-Avila F, Esteban $\mathrm{R}$, Lurie Y: Extending combination therapy with peginterferon alfa- $2 b$ plus ribavirin for genotype 1 chronic hepatitis $C$ late responders: a report of 9 cases. Hepatology 2003;37: 1226-1227.

17 Berg T, von Wagner M, Nasser S, Sarrazin C, Heintges T, Gerlach T, Buggisch P, Goeser T, Rasenack J, Pape GR, Schmidt WE, Kallinowski B, Klinker H, Spengler U, Martus P, Alshuth U, Zeuzem S: Extended treatment duration for hepatitis $C$ virus type 1: comparing 48 versus 72 weeks of peginterferonalfa-2a plus ribavirin. Gastroenterology 2006;130:1086-1097.

18 Sánchez-Tapias JM, Diago M, Escartín P, Enríquez J, Romero-Gómez M, Bárcena R, Crespo J, Andrade R, Martínez-Bauer E, Pérez R, Testillano M, Planas R, Solá R, García-Bengoechea M, Garcia-Samaniego J, Muñoz-Sánchez M, Moreno-Otero R; TeraViC-4 Study Group: Peginterferon-alfa2a plus ribavirin for 48 versus 72 weeks in patients with detectable hepatitis $\mathrm{C}$ virus RNA at week 4 of treatment. Gastroenterology 2006;131:451-460.

19 Pearlman BL, Ehleben C, Saifee S: Treatment extension to 72 weeks of peginterferon and ribavirin in hepatitis $c$ genotype 1 -infected slow responders. Hepatology 2007;46:16881694. 
-20 Akuta N, Suzuki F, Hirakawa M, Kawamura Y, Yatsuji H, Sezaki H, Suzuki Y, Hosaka T, Kobayashi M, Kobayashi M, Saitoh S, Arase Y, Ikeda K, Kumada H: A matched case-controlled study of 48 and 72 weeks of peginterferon plus ribavirin combination therapy in patients infected with $\mathrm{HCV}$ genotype $1 \mathrm{~b}$ in Japan: amino acid substitutions in HCV core region as predictor of sustained virological response. J Med Virol 2009;81:452-458.

-21 Nousbaum JB, Cadranel JF, Savary O, Legrand MC, Dumouchel P, Gouérou H: Sustained virological response after a short course of treatment with interferon and ribavirin in two chronic hepatitis $\mathrm{C}$ patients. J Hepatol 2003;39:655-656.
-22 Dalgard O, Bjøro K, Hellum KB, Myrvang B, Ritland S, Skaug K, Raknerud N, Bell H Treatment with pegylated interferon and ribavarin in $\mathrm{HCV}$ infection with genotype 2 or 3 for 14 weeks: a pilot study. Hepatology 2004;40:1260-1265

23 Nagase Y, Yotsuyanagi H, Okuse C, Yasuda K, Kato T, Koike K, Suzuki M, Nishioka K, Iino S, Itoh F: Effect of treatment with interferon alpha- $2 \mathrm{~b}$ and ribavirin in patients infected with genotype 2 hepatitis $\mathrm{C}$ virus. Hepatol Res 2008;38:252-258.

24 Nomura H, Miyagi Y, Tanimoto H, Ishibashi $\mathrm{H}$ : Impact of early viral kinetics on pegylated interferon alpha $2 \mathrm{~b}$ plus ribavirin therapy in Japanese patients with genotype 2 chronic hepatitis C. J Viral Hepat 2009;16:346-351.

-25 Toyoda H, Kumada T, Kiriyama S, Sone Y, Tanikawa M, Hisanaga Y, Kanamori A, Atsumi H, Nakano S, Arakawa T: Eight-week regimen of antiviral combination therapy with peginterferon and ribavirin for patients with chronic hepatitis $\mathrm{C}$ with hepatitis $\mathrm{C}$ virus genotype 2 and a rapid virological response. Liver Int 2009;29:120-125.
6 Murakami T, Enomoto N, Kurosaki M, Izumi N, Marumo F, Sato C: Mutations in nonstructural protein $5 \mathrm{~A}$ gene and response to interferon in hepatitis $C$ virus genotype 2 infection. Hepatology 1999;30:1045-1053.

27 Akuta N, Suzuki F, Suzuki Y, Sezaki H, Hosaka T, Someya T, Kobayashi M, Saitoh S, Arase Y, Ikeda K, Kobayashi M, Kumada H: Hepatocyte steatosis is an important predictor of response to interferon (IFN) monotherapy in Japanese patients infected with HCV genotype 2a: virological features of IFN-resistant cases with hepatocyte steatosis. J Med Virol 2005;75:550-558. 